\title{
Drexel Library School Students
}

\section{Where Do They Come from and Where Do They Go?}

\begin{abstract}
Examination was made of recent graduates of Drexel's library science program to determine their baccalaureate origins, their original residences, and the positions they held following graduation. Although these graduates came from homes in eighteen states, most originated in the Middle Atlantic area and the Northeast-60 per cent from Pennsylvania. They had graduated from 161 colleges and universities, 65 per cent of which were in the Middle Atlantic and Northeastern areas. Fifty-eight per cent accepted positions in the state of their original residence. Further statistics showing geographic distribution are given in five appended tables.
\end{abstract}

$\mathrm{T}_{\mathrm{H}}$ HE PURPOSE of this study of Drexel Institute of Technology library science graduates is to note and draw conclusions from (1) the original residence of each student before his Drexel enrollment; (2) the areas in which these graduates now hold jobs, especially as those areas coincide with the original "home" areas; and, (3) equally as interesting, the undergraduate colleges and universities which the students represent.

The statistics used for this study were compiled from various student groups: (1) for residence, the 1960-63 graduating classes, totaling 221 students; (2) for the undergraduate colleges and universities attended, from the graduates of 1954-60, and the students enrolled in January 1964. Drexel's fifty information science majors were not included in this study.

It must be understood that this study

Miss Forsyth is Bibliographical Assistant and Dr. Harvey is Dean, Graduate School of Library Science, Drexel Institute of Technology, Philadelphia. is limited by the span of years being considered in each set of statistics. Conclusions are not necessarily applicable to all Drexel graduates or to all periods of time. They are also limited by the low level of statistical significance of most of the figures used. One of the values of this study may lie in its uniqueness, however, since it is one of the few descriptions of its kind in existence in library literature. It is essentially a study of primary and secondary student markets.

\section{Original Residence}

The original residences of Drexel 1960 1963 graduates represented eighteen states plus the District of Columbia. Table 1 summarizes original residences. The biggest concentration is in the Middle Atlantic and Northeast areas. Sixty per cent of the students came from Pennsylvania and, except for the 4 per cent coming from western Pennsylvania, all of them were from Philadelphia and eastern Pennsylvania. The latter is being considered separate from Philadelphia in this study, mainly because of the signifi- 
TABLE 1

Graduates 1960-63 Geographic Study

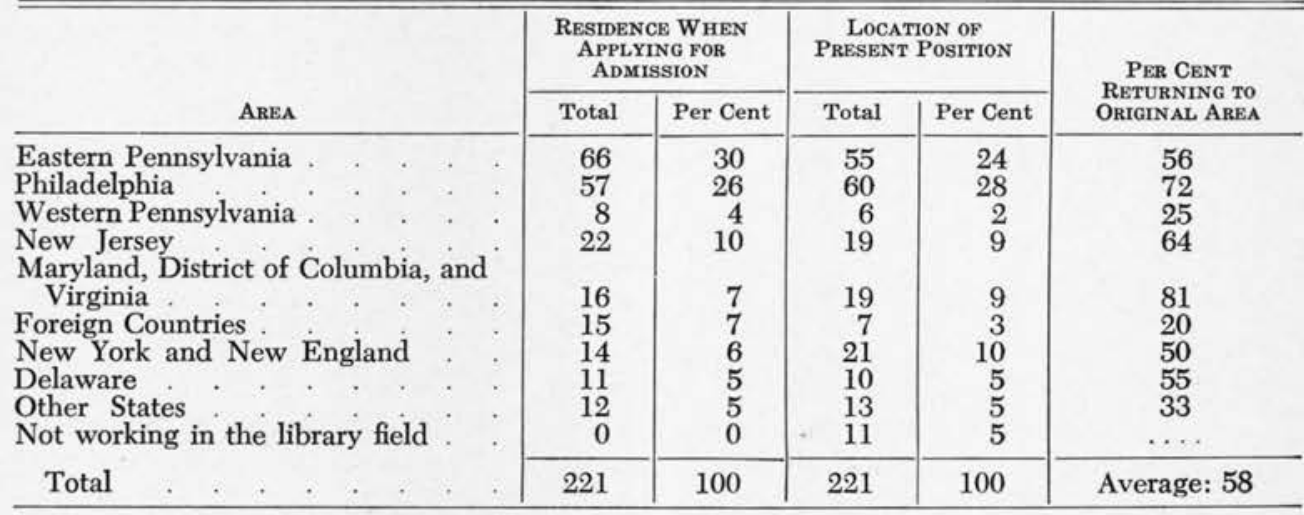

cance of the number of students which Drexel draws from the city itself. Eastern Pennsylvania, which includes suburban Philadelphia, comprises the rest of the eastern half of the state.

Ten per cent of the students were from New Jersey; 7 per cent from Maryland, District of Columbia, and Virginia combined; 6 per cent from New York and New England combined; and 5 per cent from Delaware. Five and a half per cent of the students came from other states: the South being represented by six students from five states; the West by five students from three states; and West Virginia by one student. Seven per cent of the students came from foreign countries. The Far East was well represented by ten students. The Middle West, surprisingly enough, provided no students in this four-year period. No students came from South America or Europe.

Examination of these figures reveals that the geographic areas Drexel serves are logical ones. There seem to be two principal factors determining the states from which Drexel attracts students. The first is proximity to Philadelphia. The second is whether or not the student's home state is served by a library school of its own, or at least one that is closer than Philadelphia. These two factors explain why certain states are better represented at Drexel than others. The two factors do not necessarily act with equal impact on the same area; for example, the farther away a state is, the more important the factor of proximity becomes.

Distance largely explains why other countries contributed only 7 per cent of Drexel's students and why the southern and western states were represented by only $5 \frac{1}{12}$ per cent of the students. The fact that the Midwest was not represented probably can be attributed equally to the distance and the presence in that area of several library schools.

The closer the state was to Philadelphia, the more students it sent to Drexel. Thus, 85 per cent of the students came from the five-state Middle Atlantic area comprising Pennsylvania (60 per cent), New Jersey (10 per cent), Maryland (6 per cent), Delaware ( 5 per cent), and New York (4 per cent). It is to be expected that Pennsylvania would have the highest percentage.

New York and New Jersey no doubt would have had higher percentages if both had not had accredited library schools. A look at comparative 1960 state population figures will explain why Maryland and Delaware, neither of which had a library school, were represented by relatively few students; they 
ranked fourth and fifth in total population among the five states providing the most students at Drexel. The following table shows the ratio of students to the 1960 population of the respective states:

Delaware . 1 student for every Eastern Pa. 1 student for every 40,572 Pa. 1 student for every 57,604 Maryland . 1 student for every 86,407 221,478 N.J. . . 1 student for every 275,763 N.Y. . . 1 student for every $1,678,235$

Probably most library schools draw most heavily from their immediate areas and least well from distant areas. Danton and Merritt found 87 per cent of California graduates, 1920-48, to have been California residents at the time of entrance. ${ }^{1}$ Howe found a heavy concentration of Denver students from the Rocky

\footnotetext{
1 J. P. Danton and LeRoy Merritt, Characteristics of the Graduates of the University of California School of Librarianship (Occasional Papers No. 22 [Urbana: University of Illinois, 1951] ), p.2.
}

Mountain area; ${ }^{2}$ Wilson found that 72 per cent of Illinois students came from the Middle West and nearly one-fourth from Illinois. ${ }^{3}$ Table XV of the Association of American Library Schools 195960 enrollment statistics shows that two schools, Catholic and Michigan, attracted students from more than half of the states of the Union, and that Drexel ranked twelfth of thirty-one schools, with twelve states represented. ${ }^{4}$

\section{Undergraduate Colleges}

The 161 undergraduate colleges and universities represented by the students enrolled in January 1964 were located in thirty-three states and the District of

${ }^{2}$ H. E. Howe, "A Study of the University of Denver School of Librarianship Graduates, 1932-38," Library Quarterly, X (October, 1940), 532-44.

${ }^{3}$ Eugene Wilson, "Pre-Professional Background of Students in a Library School," Library Quarterly, VIII (April 1938), 169.

4 "Accredited Library School Enrollment Statistics: 1959-60," Journal of Education for Librarianship, IV (Winter 1964), 169-81.

TABLE 2

Library Science Students Enrolled, January 1964 Undergraduate Colleges Represented

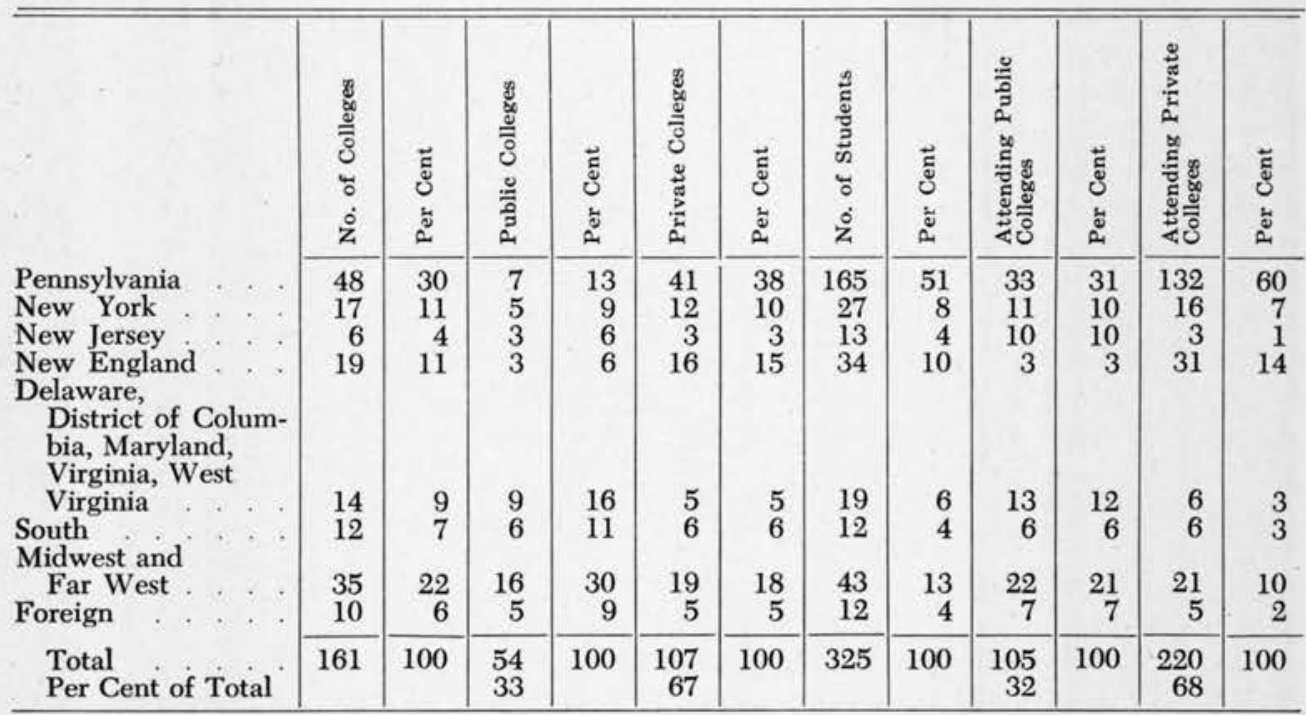

Number of States Represented: 33 plus District of Columbia

Students from Ivy League colleges: 39

Students from other prestige colleges: 32 
Columbia. Table 2 summarizes this picture. Sixty-five per cent of the colleges were in the Middle Atlantic and Northeast areas. Pennsylvania led with 30 per cent of the total. Twenty per cent of the colleges were located in the Midwest, 7 per cent in the South, and Californiathe only state represented west of the Mississippi-had 2 per cent, or three colleges. Six per cent were foreign. In a previous study, Danton and Merritt found 81 per cent of California graduates to have bachelors degrees from California colleges, a striking concentration. ${ }^{5}$

Sixty-seven per cent of the colleges were private, and 33 per cent were public. The private colleges were most heavily concentrated in the Middle Atlantic and Northeast areas; the public colleges were in the Midwest and South. The percentage of private colleges may seem high, but Drexel's primary service area is the East, which has a relatively high percentage of private colleges, and more private college graduates seem to be attracted to a privately supported library school than would be attracted to a public institution. Howe found much the same picture for Denver graduates (concentration in private institutions), ${ }^{6}$ but Wilson found Illinois students divided evenly between public and private institutions. $^{7}$

By comparing the percentages of colleges attended in each state with the percentage of students attending them, as shown in Table 2, it can be seen that the closer the state is to Philadelphia, the more heavily concentrated were the students from these colleges. For example, Pennsylvania had 30 per cent of the colleges and 51 per cent of the students, New England 11 and 10 per cent, New Jersey and New York 15 and 12 per cent. On the other hand, the Midwest and Far West had 22 per cent of the colleges but only 13 per cent of the students attended

\footnotetext{
${ }^{5}$ Danton and Merritt, op. cit., p.2.

6 Howe, op. cit., p.533.

Wilson, op. cit., pp.157-88.
}

them, and the South had 7 per cent and 4 per cent.

Twenty-two per cent of the students went to Ivy League or other high-prestige colleges and universities. ${ }^{8}$

Tables 3 and 4 summarize individual colleges attended. The leading feeder colleges in 1954 60 were the University of Pennsylvania, Pennsylvania State University (not shown), Temple (not shown), Ursinus, Delaware, and Millersville. Combined, they provided 25 per cent of the 497 Drexel students.

There is a considerable concentration of the colleges in Table 3 around Philadelphia, eleven of the twenty colleges being in the city (1) or its suburbs (10).

\footnotetext{
"The designation "high-prestige" is based on a rating of top colleges and universities compiled by Chesly Manly in Newsweek, May 6, 1959, p.74.
}

TABLE 3

Undergraduate Colleges Leading in ENROLLMENT AT DREXEL. 1954-1960

\begin{tabular}{|c|c|c|c|}
\hline Colleges & $\begin{array}{c}\text { Approxi- } \\
\text { mate } \\
\text { Under- } \\
\text { graduate } \\
\text { Enroll- } \\
\text { ment* }\end{array}$ & $\begin{array}{c}\text { Graduates } \\
\text { at } \\
\text { Drexel }\end{array}$ & $\begin{array}{l}\text { Percentage } \\
\text { of Total } \\
\text { Under- } \\
\text { graduate } \\
\text { Enroll- } \\
\text { ment }{ }^{\dagger}\end{array}$ \\
\hline Ursinus ... & 800 & 18 & 2.3 \\
\hline Eastern Baptist & 300 & 6 & 2.0 \\
\hline Immaculata . . & 600 & 7 & 1.2 \\
\hline Wilson ... . & 500 & 5 & 1.0 \\
\hline Earlham & 800 & 6 & 0.8 \\
\hline Chestnut Hill . & 600 & 5 & 0.8 \\
\hline Maryville . . & 600 & 5 & 0.8 \\
\hline Haverford . . & 400 & 3 & 0.8 \\
\hline Bryn Mawr . & 900 & 6 & 0.7 \\
\hline Beaver . . & 600 & 4 & 0.7 \\
\hline Juniata & 700 & 5 & 0.7 \\
\hline $\begin{array}{l}\text { Millersville State } \\
\text { Univ. of }\end{array}$ & 1,500 & 10 & 0.7 \\
\hline Delaware . & 2,000 & 14 & 0.7 \\
\hline Swarthmore . & 900 & 5 & 0.6 \\
\hline Dickinson . & 1,000 & 5 & 0.5 \\
\hline $\begin{array}{l}\text { Susquehanna. . } \\
\text { Univ. of }\end{array}$ & 600 & 3 & 0.5 \\
\hline Pennsylvania. & 12,000 & 47 & 0.4 \\
\hline $\begin{array}{l}\text { Western } \\
\text { Maryland }\end{array}$ & & & \\
\hline $\begin{array}{l}\text { Maryland } \\
\text { West Chester }\end{array}$ & 700 & 3 & 0.4 \\
\hline State & 2,000 & 5 & 0.3 \\
\hline Vassar . . . & 1,200 & 3 & 0.3 \\
\hline
\end{tabular}

* Figures from The World Almanac, 1961.

† Column 4 is obtained by dividing the numbers in column 3 by those in column 2 . Of course, the statistical level of significance of these figures is low. 
TABLE 4

Undergraduate Colleges Leading in ENROLLMENT AT DREXEL JANUARY $1964^{\circ}$

\begin{tabular}{|c|c|c|c|}
\hline Colleges & $\begin{array}{c}\text { Approxi- } \\
\text { mate } \\
\text { Under- } \\
\text { graduate } \\
\text { Enroll- } \\
\text { ment }\end{array}$ & $\begin{array}{c}\text { Graduates } \\
\text { at } \\
\text { Drexel }\end{array}$ & $\begin{array}{l}\text { Per Cent } \\
\text { of Total } \\
\text { Enroll- } \\
\text { ment }\end{array}$ \\
\hline Ursinus . & 900 & 6 & 0.6 \\
\hline Immaculata . & 700 & 4 & 0.6 \\
\hline $\begin{array}{l}\text { West Chester } \\
\text { State }\end{array}$ & 2,400 & 12 & \\
\hline Rosemont : & 600 & 3 & 0.5 \\
\hline $\begin{array}{l}\text { Univ. of } \\
\text { Pennsylvania . }\end{array}$ & 12000 & & \\
\hline Temple. & $\begin{array}{l}12,000 \\
16,000\end{array}$ & $\begin{array}{l}31 \\
32\end{array}$ & $\begin{array}{l}0.3 \\
0.2\end{array}$ \\
\hline Smith & 2,300 & 5 & 0.2 \\
\hline Bucknell & 2,400 & 4 & 0.2 \\
\hline Wellesley. & 1,700 & 3 & 0.2 \\
\hline Glassboro State & 1,600 & 3 & 0.2 \\
\hline Wilkes . . & 1,500 & 3 & 0.2 \\
\hline Radcliffe : & 1,500 & 3 & 0.2 \\
\hline Middlebury . & 1,300 & 3 & 0.2 \\
\hline $\begin{array}{l}\text { Pennsylvania } \\
\text { State Univ. }\end{array}$ & & & \\
\hline State Univ. & 15,000 & 12 & 0.1 \\
\hline Rutgers . & 5,800 & 6 & 0.1 \\
\hline Hunter : . . & 6,900 & 5 & 0.1 \\
\hline Columbia . . & 4,000 & 3 & 0.1 \\
\hline
\end{tabular}

- Notice that this table differs somewhat from Table 4 in covering the enrollment for only one quarter. The tables use the same minimum number of Drexel students, three for each college, however, and also omit certain universities which provided more than three students but had a low score in column 4.

$\dagger$ Based on figures from Lovejoy's College Guide, 1961-62.

$\ddagger$ Column 4 is obtained by dividing the numbers in column 3 by those in column 2. Of course, the statistical level of significance of these figures is low.

Two of the colleges, Earlham and Maryville, were more than five hundred miles away, however, and several others were more than one hundred miles away.

It seems clear that the small liberal arts college scored best in Table 3 , few state colleges (2) or large universities (1) being represented. Colleges with strong religious emphasis (perhaps 6) and with primarily women students (7) seem to have been represented in betterthan-average numbers, and one men's college was included. In percentage of the student body represented at Drexel, Ursinus, Eastern Baptist, Immaculata, and Wilson obviously were prime feeders.

Sixty-three, or 19 per cent, of the total number for 1964 went to the University of Pennsylvania and Temple University combined, as shown in Table 4. West Chester State, Pennsylvania State University, and Ursinus College also were leaders. Certain out-of-state colleges were well represented: Rutgers University (even though it has a library school of its own), Hunter, and Smith.

Although Temple University and the University of Pennsylvania led all colleges in providing students, their student bodies were also quite large. In terms of percentage of total enrollment, the University of Pennsylvania sent 0.3 per cent of its students (or 1 for every 325 enrolled) to Drexel, and Temple sent 0.2 per cent (or 1 for every 500 students).

Outstanding in the percentage of their students who enrolled at Drexel were Ursinus, with approximately 0.6 per cent (or 1 Drexel student for every 150 Ursinus students enrolled); Immaculata (1 for every 175 students), West Chester (1 for every 200 students), and Rosemont ( 1 for every 200 students). These were prime feeders for Drexel. All are located within twenty miles of Philadelphia. Several other colleges located from one to ten miles away, however, sent fewer students.

Of the colleges listed in Tables 3 and 4, only four are repeated: Ursinus, Immaculata, University of Pennsylvania, and West Chester State. In terms of percentages they were the most consistent prime feeders. To the list of institutions consistently sending comparatively large numbers of students, Temple, Delaware, and Pennsylvania State University should be added. Large universities (6) increased considerably in the second list and colleges with religious emphasis decreased. Average college enrollment went up considerably. The number of Ivy League or other high-prestige colleges remained about the same, about half a dozen in each list. Institutions with city or state support increased in number. This level of concentration may be 
compared with that found by Danton and Merritt in which about 50 per cent of their students had bachelors degrees from one campus, that at Berkeley, ${ }^{9}$ and with Richards who found 68 per cent to have done their undergraduate work at the University of Washington. ${ }^{10}$

\section{Location of Positions}

Fifty-eight per cent of Drexel Library Science graduates accepted positions in the state of their original residence. But the longer the distance the student had to come to Drexel, the less likely he was to return to his home area to work, as is shown in Table 5 . Thus, the five states in the Philadelphia area had the highest rate of return. Maryland was highest, with 85 per cent of its residents returning. The rate of return to Philadelphia was 72 per cent. New Jersey was next, with 64 per cent, followed by Delaware and New York, with 55 and 33 per cent respectively, below the average. Howe, Richards, and Morton also found heavy concentrations of graduates returning to the region, or even the state, around the school which produced them. ${ }^{11}$

'Danton and Merritt, op. cit., p.2.

10 J. S. Richards, "Regional Service of a Library School," PNLA Quarterly, V (January 1941), 79-82.

II Howe, op. cit., p.540 ; Richards, op. cit., p.80; F. F. Morton, "First 504," Louisiana Library Association Bulletin, X (January 1947), 39-41.
For the most part, the graduates from those states with lower rates of return accepted positions in the Pennsylvania area, probably most of them in Philadelphia. For example, 27 per cent from Delaware accepted positions in Pennsylvania, as did 33 per cent from the western and southern states. Of those from foreign countries who did not return to their original residences, 33 per cent accepted positions in Pennsylvania, and 27 per cent accepted positions in New York state.

The fact that 42 per cent did not return to their home areas to work indicates a fair amount of geographic mobility. Although no one state or city attracted the graduates in excessively large numbers, 87 per cent did go to the Middle Atlantic and Northeast areas.

Approximately the same percentage accepted positions in an area as came from that area, though the two groups were not necessarily made up of the same people. For example, about 60 per cent of the total number of students came from Pennsylvania and 55 per cent, upon graduation, accepted positions there. Likewise, 5 per cent came from Delaware, and 5 per cent went there for positions.

There were, however, some differences

TABLE 5

Numbers of Graduates 1960-63 GeOgRAPHic Study

\begin{tabular}{|c|c|c|c|c|c|c|c|c|c|c|c|}
\hline \multirow[b]{2}{*}{ ORIGINAL RESIDENCE } & \multirow[b]{2}{*}{ TOTAL } & \multicolumn{10}{|c|}{ Present Position } \\
\hline & & E. Pa. & Phila. & w. Pa. & N.J. & $\begin{array}{l}\text { Md., } \\
\text { D.c. } \\
\text { \& Va. }\end{array}$ & $\begin{array}{l}\text { For- } \\
\text { eign }\end{array}$ & $\begin{array}{l}\text { N.Y.\& } \\
\text { N.Eng. }\end{array}$ & Del. & $\begin{array}{l}\text { Other } \\
\text { States }\end{array}$ & $\begin{array}{c}\text { Not } \\
\text { Work- } \\
\text { ing } \\
\end{array}$ \\
\hline Eastern Pennsylvania & 66 & 37 & 7 & 3 & 1 & 2 & 4 & 3 & 3 & 1 & 5 \\
\hline Philadelphi & 57 & 6 & 41 & 0 & 2 & $\overline{2}$ & 0 & 1 & 0 & 3 & 2 \\
\hline Western Pennsylvania & 8 & 3 & 2 & 2 & 0 & $\overline{0}$ & 0 & 1 & 0 & 0 & $\overline{0}$ \\
\hline New Jersey & 22 & 4 & 0 & 0 & 14 & 0 & 0 & 1 & 1 & 2 & 0 \\
\hline $\begin{array}{l}\text { Maryland, District of } \\
\text { Columbia, and }\end{array}$ & & & & & & & & & & & \\
\hline Virginia . . . & 16 & 1 & 2 & 0 & 0 & 13 & 0 & 0 & 0 & 0 & 0 \\
\hline $\begin{array}{l}\text { Foreign } \\
\text { New York and New }\end{array}$ & 15 & 1 & 4 & 0 & 0 & 0 & 3 & 5 & 0 & 1 & 1 \\
\hline $\begin{array}{l}\text { New York and New } \\
\text { England }\end{array}$ & 14 & 0 & 1 & 0 & 2 & 1 & 0 & 7 & 0 & 1 & 2 \\
\hline Delaware & 11 & 1 & 1 & 1 & 0 & 0 & 0 & 1 & 6 & 1 & 0 \\
\hline Other states & 12 & 2 & 2 & 0 & 0 & 1 & 0 & 2 & 0 & 4 & 1 \\
\hline Total .... & 221 & 55 & 60 & 6 & 19 & 19 & 7 & 21 & 10 & 13 & 11 \\
\hline
\end{tabular}


in the percentage of students originating from and the percentage accepting positions in certain areas. Most of these differences were slight, except-perhapsfor that of the foreign countries. For example, more graduates accepted positions in New York and New England (10 per cent) than came from that area (6 per cent), probably because of the attraction of New York City. On the other hand, fewer accepted positions in eastern Pennsylvania (24 per cent) than came from there ( 30 per cent). This is also true of foreign countries, with 3 per cent accepting positions abroad, although 7 per cent came from there originally.

Eleven of the graduates are not working as librarians at the present time. Though this may seem to be a low rate, it is still a disappointment if only because of the shortage of librarians. Five are women-all of whom are housewives and are not gainfully employed. The other four are men-one is a parish priest, one an assistant professor of history, another is continuing his studies, the occupation of one is unknown; two are deceased.

For purposes of clarification and correction, the author of the paper "Statistical Method for Circulation Analysis," CRL $\mathrm{XXV}, 488-90$, retraces as follows the pertinent mathematical formulae:

Let $\mathrm{T}=$ number of days of observation

$\mathrm{N}=$ total number of loans

$A_{i}=$ length of time copy was kept out

$\overline{\mathrm{A}}=$ average length of time all copies then were kept out

$$
\begin{aligned}
\overline{A_{1}} & =\left(\operatorname{sum} \text { of } A_{1}\right) / N \\
& =102 / 15 \\
& =6.8
\end{aligned}
$$

\section{Conclusions}

Several additional conclusions can be drawn from this study. Drexel had a fairly broad geographic base in terms of the residences and undergraduate colleges represented by its students; for example, 35 per cent of the colleges attended were not in the East. It attracted students more by virtue of their home residences than their colleges, as can be seen by comparing the difference between eighteen states representing original residences and thirty-three representing the colleges attended.

To some extent Drexel served as a Philadelphia or Delaware Valley library school; 50 per cent of its students listed Philadelphia as their residence, and 26 per cent went to colleges in that area. To an even greater extent, however, Drexel tended to serve the five-state region around it; 85 per cent of the students resided in that area prior to admission, and 67 per cent went to colleges in these states. It is obvious that Drexel served to a much lesser extent as a national or international library school.

\section{Corrigenda}

$$
\begin{aligned}
\mathrm{N}_{\mathrm{av}} & =\text { average number of books on loan } \\
& =(\mathrm{N} / \mathrm{T}) \times(\overline{\mathrm{A}}) \\
& =2.55 \\
\mathrm{~S} & =\text { standard deviation } \\
& =\sqrt{ }\left(\text { sum of }\left(\mathrm{A}_{\mathrm{i}}-\overline{\mathrm{A}}\right)\right) / \mathrm{N} \\
& =\sqrt{ } 102.4 / 15 \\
& =2.61 \\
\mathrm{~N}_{99 \%}= & \mathrm{N}_{\mathrm{av}}+3 \mathrm{~S} \\
= & 2.55+3 \times 2.61 \\
& =10.38 \\
& =\text { maximum number of books on } \\
& \text { loan } 99 \text { per cent of the time. }
\end{aligned}
$$

